\title{
MORPHOLOGICAL CHANGES IN ASTACUS ASTACUS GONADS DURING THE REPRODUCTIVE CYCLE
}

\author{
A. LUCIĆ, R. ERBEN, G. LACKOVIĆ
}

Department of Zoology, Faculty of Science, University of Zagreb, Rooseveltov trg 6, 10000 Zagreb, Croatia. E-mail: andreja@biol.pmf.hr

Reçu le 16 juin 2005

Received June 16, 2005

Accepté le 21 novembre 2005

\author{
Accepted November 21, 2005
}

\begin{abstract}
The reproductive cycle of Astacus astacus was described by the external observation of the gonads, recording changes in the gonadosomatic index (GSI) and by the histological analysis of the reproductive organs. A total of 37 males and 13 females of Astacus astacus were collected from the Vukovina gravel pit located at northwest Croatia from May 2003 until January 2004. All crayfish were mature with total body lengths between 7.84 and $13.7 \mathrm{~cm}$ and weights between 16 and $125 \mathrm{~g}$. There was a pronounced difference between the GSI values of the sexes. GSI fluctuated within a very small range (between 0.2 and $1.5 \%$ ) in males while in females it increased up to $12.3 \%$ during the mating season. The external appearance of the testes and ovaries during the reproductive cycle was compared with the histological sections of germ cells in the testes, the vas deferens and ovaries. Besides the germinative cells, the morphological changes in testis and vasa deferentia of $A$. astacus extended also to the connective tissue and secretory epithelium. The maturation of germinative cells was synchronized, both in testes and ovaries.
\end{abstract}

Key-words: Astacus astacus, reproductive cycle, gonadosomatic index, gonads, histology.

\section{LES CHANGEMENTS MORPHOLOGIQUES DES GONADES D'ASTACUS ASTACUS PENDANT LE CYCLE REPRODUCTIF}

\section{RÉSUMÉ}

Le cycle reproductif d'Astacus astacus a été décrit par l'observation externe des gonades, en enregistrant les changements de l'indexe gonadosomatique (GSI), et par l'analyse histologique des organes reproductifs. De mai 2003 à janvier 2004, 37 mâles et 13 femelles d'Astacus astacus ont prélevées dans une mine de gravier près de Vukovina qui se trouve au Nord Ouest de la Croatie. Toutes les écrevisses récoltées étaient mûres, mesuraient de 7,84 à $13,7 \mathrm{~cm}$ de longueur totale et pesaient de 16 à $125 \mathrm{~g}$. II y a une différence accentuée entre les valeurs de GSI des deux sexes. Chez les mâles les valeurs de GSI ont oscillé sur une toute petite amplitude (entre 0,2 et $1,5 \%$ ) tandis que chez les femelles il a atteint $12,3 \%$ pendant la période reproductive. L'apparence externe des testicules et des ovaires pendant le cycle reproductif a été comparée aux coupes histologiques des cellules germinatives dans les testicules, les canaux déférents et les ovaires. Des changements morphologiques sont observés sur les testicules, les canaux déférents et les ovaires et s'étendent au tissu connectif et à l'épithélium sécréteur. La maturation des cellules germinatives est synchronisée dans les testicules aussi bien que dans les ovaires. histologie.

Mots-clés : Astacus astacus, cycle reproductif, gonades, indexe gonadosomatique, 


\section{INTRODUCTION}

Crayfish are unisexual animals having males and females although intersex individuals also occur in low frequencies. In both sexes the gonads lie dorsally in the thorax and their size and appearance depend on the age and reproduction condition of the individuals (VOGT, 2002).

The testes consist of paired anterior lobes and one posterior lobe. They are covered by a thin cortex made up of an outer epithelial layer and an inner connective tissue layer (KROL et al., 1992). Each testicular lobe consists of many seminiferous tubules which are lined by nurse cells and surrounded by hemal sinuses. The structure and appearance of the seminiferous tubules varies with the stage of spermatogenesis. Spermatogenesis is synchronized within seminiferous tubules and particular regions of the testes (OBRADOVIĆ, 1982). Mature decapod spermatozoa are aflagellate and have a decondensed nucleus and variable number of spikes (KROL et al., 1992). Collecting tubules collect sperm from the seminiferous tubules and transport it to the vas deferens. The vas deferens which are attached to the testes are very long, the paired tubular ducts through which spermatozoa pass from the collecting tubes of the testes to the gonopores which open at the base of the fifth pair of the pereiopod. They are composed of a secretory epithelium which have variety of functions (transport of the spermatozoa down to the ducts, the maintenance of an appropriate environment for the spermatozoa, and the production of a protective covering) and are surrounded by connective tissue (ADIYODI and ANIKUMAR, 1988). When spermatozoa enter the vas deferens they consolidate the sperm mass and secrete acellular spermatophore wall layers (VOGT, 2002).

Ovaries, similarly to testes, consist of two anterior and one posterior lobe, which are covered by thin muscle and connective tissue layers (VOGT, 2002). The germinal epithelium (germarium) from which the oogonia and follicle cells are derived lies centrally in the ovarian lobes. Follicle cells are the only nongerminative cells within the ovarian lobes (KROL et al., 1992). During the oocyte growth and vitellogenesis, follicle cells move from the germinal epithelium into the growth zone and attach to the periphery of each oocyte, thus forming oogenetic pouches. Each oogenetic pouch contains a single mature egg or single previtellogenic or vitellogenic oocyte (ANDO and MAKIOKA, 1999). MEUSY and PAYEN (1988) separated ovarian development into previtellogenesis, vitellogenesis, oocyte growth and maturation. During previtellogenesis the secondary oogonia leave the germinal zone and progress to previtellogenic oocytes, which are characterized by amorphous, basophilic cytoplasm (TAN-FERMIN and PUDADERA, 1989). The next phase, vitellogenesis involves the assembly of organic and inorganic components of yolk in the developing oocyte (BROWDY et al., 1990). As vitellogenesis proceeds, yolk accumulates and oocytes mature synchronously in ovarian lobes. Vitellogenic oocytes mature and move to the periphery of the ovary, which causes the expansion of ovarian lobes into the hemocoelic space (KROL et al., 1992). The culmination of oocyte maturation occurs several hours before spawning (YANO, 1988). ADIYODI and SUBRAMONIAM (1983) divided oogenesis into two phases: the proliferative phase and the differentiative phase. During the proliferative phase, secondary oogonia are produced in the germinal zone by mitotic divisions. In the differentiative phase, the secondary oogonia enter into the prophase of meiosis and primary oocytes are derived and displaced toward the growth zone. The oocyte increases in size, mature and when ovulation occurs the meiotic division progresses to the metaphase of primary maturation division (YANO, 1988). The ovaries are associated with short, paired oviducts that lead to paired gonopores, which open at the base of the third pereiopods. The oviducts are surrounded by fibrous connective tissue and muscle fibbers (KROL et al., 1992).

Most of the studies on decapod gonads concentrated on ovarian functions (YANO, 1988; MINAGAWA et al., 1993), vitellogenesis (SUBRAMONIAM, 2000; ABDU et al., 2000) and the seasonal changes of the ovarian activities (O'DONOVAN et al., 1984) while the 
testis have not been so thoroughly studied (SELLOS and LEGAL, 1981; OBRADOVIĆ, 1982; ADIYODI and ANIKUMAR, 1988). In this study, we examined the morphological changes in both testes and ovaries of Astacus astacus during the reproductive cycle, their synchrony with the external observations of gonads and changes in the gonadosomatic indices.

\section{MATERIAL AND METHODS}

A total of 37 males and 13 females of Astacus astacus were collected from the Vukovina gravel pit located at northwest Croatia. Crayfish were trapped by baited LiNi traps (WESTMAN et al., 1978). Males were caught each month from May 2003 until January 2004 and females were caught each month from May 2003 until October 2003. All crayfish were mature with total body lengths between 7.84 and $13.7 \mathrm{~cm}$ and weights between 16 and $125 \mathrm{~g}$. The appearance of glair glands, white, yellow or brown eggs in females and mature swollen testis in males were recorded by exterior observations. Observations were done by pushing the tail down and pulling the carapax up which enable the observation of colour and appearance of gonads located dorsally in the cephalothorax. Changing colouration of eggs from white to brown indicated their maturation. Crayfish were sacrificed and dissected within 24 hours of trapping. Gonads were weighed and then approximately half of the gonads were dried at $80^{\circ} \mathrm{C}$ for 24 hours and half were fixed with Bouin's solution for 24 hours. Gonads were weighed again after drying and the gonadosomatic index and the gonad moisture content were recalculated for the whole organ. The gonadosomatic index (GSI) was calculated as follows (JUSSILA, 1997)

$\mathrm{GSI}=\mathrm{W}_{\mathrm{wh}} \times 100 / \mathrm{W}_{\mathrm{t}}$

where $\mathrm{W}_{\text {wh }}$ is wet gonad weight and $\mathrm{W}_{t}$ is total weight of crayfish.

Gonad moisture content (GM) was calculated as follows

$\mathrm{GM}=\left(\mathrm{W}_{\mathrm{wh}}-\mathrm{W}_{\mathrm{dh}}\right) \times 100 / \mathrm{W}_{\mathrm{wh}}$

where $W_{w h}$ is wet gonad weight and $W_{d h}$ is dry gonad weight.

After fixation gonads were dehydrated in a graded ethanol series and embedded in Paraplast (Sigma, P-3683). 8-10 $\mu \mathrm{m}$ thick sections were stained with Mayer's haematoxylin and eosin (H \& E) for morphological analysis, and Periodic Acid Schiff (PAS) reaction for complex carbohydrates (ŠVOB, 1974).

\section{RESULTS}

Some physiological activities connected with the reproductive cycle are presented in Table I. Females with the glair glands were recorded for the first time in August and then in the next two months. White eggs were present in all females caught, yellow eggs were present for the first time in June and brown eggs appeared for the first time in August. Females were not caught from November 2003 until May next year while males were active and regularly trapped from May 2003 until January 2004. Mature swollen testes were recorded for the first time in September.

The relative weight of the gonads increased in both sexes as the mating season approached (Table II). The gonadosomatic index of males fluctuated from May to January within a very small range, i.e. between 0.2 measured in July and $1.5 \%$ measured in November. The moisture content of the testes decreased from around $80 \%$ measured in May to approximately $70 \%$ measured in November. The relative ovarian weight gradually increased from $0.7 \%$ measured in May to as high as $12.3 \%$ measured in October. Lower ovarian moisture content (66\%) was detected in May while during the next few months the moisture content varied between 70 and $85 \%$. 
Table I

Physiological activities of $A$. astacus recorded from May 2003 until January 2004.

Tableau I

Activités physiologiques d'A. astacus enregistrées entre mai 2003 et janvier 2004.

\begin{tabular}{|l|c|c|c|c|c|c|c|c|c|}
\hline & May & June & July & Aug. & Sept. & Octob. & Nov. & Dec. & Jan. \\
\hline Activity F/M & $+/+$ & $+/+$ & $+/+$ & $+/+$ & $+/+$ & $+/+$ & $-/+$ & $-/+$ & $-/+$ \\
\hline Molting & + & + & + & + & + & + & & & \\
\hline Glair glands & & & & + & + & + & & & \\
\hline Mature testis & & & & & + & + & + & & \\
\hline White eggs & + & + & + & + & + & + & & & \\
\hline Yellow eggs & & + & + & + & + & + & & & \\
\hline Brown eggs & & & & + & + & + & & & \\
\hline Mating & & & & & & & + & + & \\
\hline
\end{tabular}

$-/+=$ activity of females/activity of males.

Table II

Mean and standard deviation of gonadosomatic index (GSI\%) and gonad moisture content (GM\%) in males and females of $A$. astacus recorded from May 2003 until January 2004.

Tableau II

Moyennes et écart-type de l'indexe gonadosomatique (GSI\%) et du contenu d'humidité des gonades (GM\%) chez les mâles et femelles d'A. astacus, enregistrées entre mai 2003 et janvier 2004.

\begin{tabular}{|l|c|c|c|c|c|c|}
\hline \multirow{3}{*}{ Month } & \multicolumn{6}{|c|}{ Astacus astacus } \\
\cline { 2 - 4 } & \multirow{2}{*}{$\mathbf{N}$} & \multicolumn{2}{|c|}{ Males } & \multicolumn{2}{c|}{ Females } \\
\cline { 3 - 4 } \cline { 6 - 7 } & & GSI\% & GM\% & & GSI\% & GM\% \\
\hline May & 9 & $0.47 \pm 0.07$ & $78.9 \pm 4.6$ & 1 & 0.73 & 65.96 \\
\hline June & 4 & $0.3 \pm 0.06$ & $82.16 \pm 2.9$ & 3 & $0.5 \pm 0.19$ & $78.87 \pm 2.4$ \\
\hline July & 4 & $0.21 \pm 0.005$ & $86.2 \pm 3.8$ & 1 & 0.47 & 83.95 \\
\hline August & 3 & $0.42 \pm 0.03$ & $84.4 \pm 1.8$ & 3 & $0.59 \pm 0.04$ & $80.28 \pm 1.6$ \\
\hline September & 3 & $0.95 \pm 0.2$ & $85.7 \pm 0.17$ & 3 & $1.57 \pm 0.59$ & $69.14 \pm 2.9$ \\
\hline October & 4 & $1.15 \pm 0.15$ & $83.8 \pm 0.8$ & 2 & $12.3 \pm 2.6$ & $84.6 \pm 0.2$ \\
\hline November & 5 & $1.53 \pm 0.08$ & $72.9 \pm 0.16$ & 0 & - & - \\
\hline December & 3 & $1.24 \pm 0.008$ & $71.5 \pm 3.5$ & 0 & - & - \\
\hline January & 2 & $1.1 \pm 0.13$ & $67.2 \pm 5.2$ & 0 & - & - \\
\hline
\end{tabular}

Morphological changes in testes, vas deferens and ovaries detected with light microscopy are presented in Table III. The seminiferous tubules are surrounded by a connective tissue layer, which is thinner from August to October (Figures 1C, D and E) then in May, July and November (Figures 1A, B and F). Differences in the appearance of the connective tissue are also indicated by the changing intensity of the PAS reaction. Very strong PAS positive connective tissue and a basal membrane of seminiferous tubules were detected in May and in November, when most of the seminiferous tubules were empty (Figures 2A and D). During the maturation of the spermatozoa (from July to September) the PAS reaction was less intensive and it was limited only to a part of the connective tissue layer and/or the basal membrane of the germ epithelium (Figures $2 \mathrm{~B}$ and $\mathrm{C}$ ). 


\section{Table III}

Morphological changes in the testes, vas deferens and ovaries of $A$. astacus recorded from May 2003 until January 2004.

Tableau III

Changements morphologiques dans les testicules, les canaux déférents et les ovaires des A. astacus, notés entre mai 2003 et janvier 2004.

\begin{tabular}{|l|l|c|c|c|c|c|c|c|c|c|}
\hline Organ & May & June & July & Aug. & Sept. & Octob. & Nov. & Dec. & Jan. \\
\hline Testes & spermatogonia & + & + & + & & & & & & \\
\hline & spermatocytes & & & + & + & & & & & \\
\hline & spermatides & & & & + & + & & & & \\
\hline & spermatozoa & & & & & + & + & & & \\
\hline $\begin{array}{l}\text { Vas } \\
\text { deferens }\end{array}$ & spermatophore & & & & & + & + & + & + & \\
\hline & $\begin{array}{l}\text { squamous } \\
\text { epithelium }\end{array}$ & + & + & + & & & & & & \\
\hline & $\begin{array}{l}\text { pseudostratified } \\
\text { columnar ciliated } \\
\text { epithelium }\end{array}$ & & & + & + & + & + & & & \\
\hline & $\begin{array}{l}\text { simple columnar } \\
\text { epithelium }\end{array}$ & & & & & & & & & \\
\hline & $\begin{array}{l}\text { simple cuboidal } \\
\text { epithelium }\end{array}$ & & & & & & & & & + \\
\hline Ovaries & \begin{tabular}{l} 
atresia \\
\hline
\end{tabular} & + & + & & & & & & & \\
\hline & $\begin{array}{l}\text { oogonia } \\
\text { previtellogenic } \\
\text { oocytes }\end{array}$ & & & + & + & + & + & & & \\
\hline & $\begin{array}{l}\text { vitellogenic } \\
\text { oocytes }\end{array}$ & & & & + & + & + & & & \\
\hline
\end{tabular}

During May and June the tubule lumen was filled with numerous spermatogonia (Figures 1A, Table III), while the first spermatocytes appeared in some seminiferous tubules in July (Figure 1B). In August, most of the seminiferous tubules were filled with the spermatocytes (Figure 1C). Primary spermatocytes could not be distinguished from secondary spermatocytes with light microscopy, but both cell types were filled with chromosomes at different stages of meiosis. For the first time mature spermatozoa were noticed together with the spermatids in seminiferous tubules of testes sampled in September (Figure 1D). Spermatids had very dense, basophilic and elongated nuclei and they were mostly located centrally in a tubule lumen. A month later, most of these tubules were filled with spermatozoa (Figure 1E). The acrosomal vesicle of the spermatozoa was basophilic and stained positive with the PAS procedure (Figures 1D, $E$ and $F, 2 C$ and $D)$.

A maximum of two cell stages of spermatogenesis were detected in one segment of seminiferous tubules at the same time. Spermatogenesis was also synchronized at a different level, in particular regions of testis, where most of the tubules were of similar appearance. The radius of seminiferous tubules were changed from approximately $50 \mu \mathrm{m}$ measured in May to approximately $200 \mu \mathrm{m}$ measured in October (Figures $1 \mathrm{~A}$ and $\mathrm{E})$. 

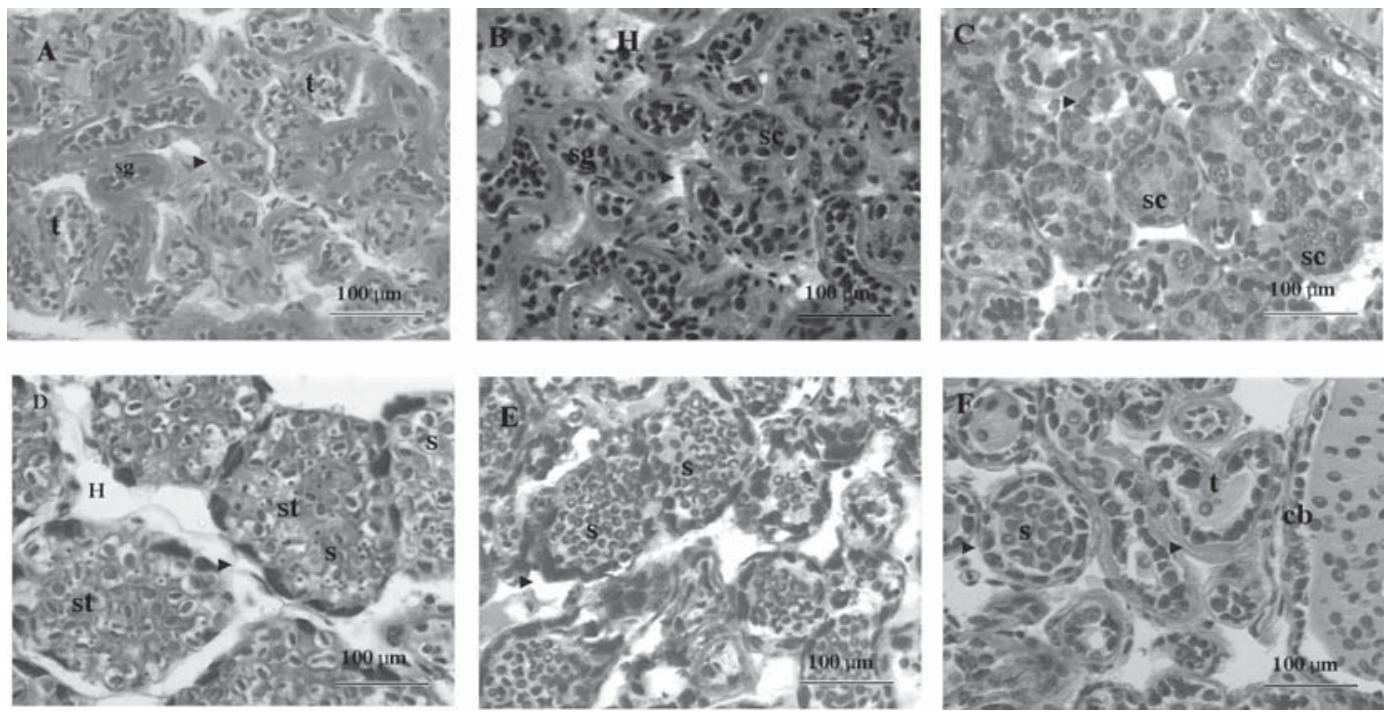

Figure 1

Seminiferous tubules in the testes of $A$. astacus caught in May (A), July (B), August (C), September (D), October (E) and November (F). Seminiferous tubules are filled with cells in different stages of spermatogenesis and nurse cells (Sertoli cells) and surrounded by thin layer of connective tissue. $t$ - seminiferous tubule; - Sertoli cells; sg - spermatogonia; sc - spermatocytes; st - spermatids; s - spermatozoa; $\mathrm{H}$ - hemal sinuses; $\mathrm{ct}$ - collecting tubule; $\mathrm{cb}$ - cuboidal epithelium. $H$ \& E method.

\section{Figure 1}

Tubules séminifères dans les testicules des $A$. astacus prises au mois de mai $(A)$, juillet (B), août (C), septembre (D), octobre (E) et novembre (F). Les tubules séminifères sont pleins de cellules à des différentes étapes de la spermatogenèse aussi bien que de cellules nourricières (cellules Sertoli) et entourés d'une couche mince de tissu connectif. $t$ - tubule séminifère ; - cellule Sertoli ; sg - spermatogonies ; sc - spermatocytes ; st - spermatides ; $\mathbf{h}$ - sinuses hemales ; ct - tubules collectifs ; cb - épithélium cuboidal. Méthode H \& E.

Changes in the epithelium and connective tissue surrounding the lumen of vasa deferentia were recorded (Figures 3 A, B, C and D). In May and June, a thick layer of eosinophilic connective tissue and simple squamous epithelium surrounds it, while it was filled with mass of cells and granular material, probably disintegrated spermatophores. In August and September pseudostratified columnar ciliated epithelium surrounded the lumen (Figure 3B) while the cells of the connective tissue layer became more flattened. An intensive positive PAS reaction in the connective tissue layer and the basement membrane of vas deferens was also noticed (Figure 3C). After the mating period in November and December, a single layered columnar ciliated epithelium was recorded (Figure 3D) while in January the epithelium has changed to single layered cuboidal. Vasa deferentia were filled with spermatophores for the first time in September (Figure 3B). Three acellular layers of the spermatophore wall were visible: an inner, a medial and an outer layer (Figures 3B, C and D). The inner layer was very thin and basophilic and it surrounded the central mass of spermatozoa (Figures 3B, C. D). The medium layer was very thick and acidophilic and constituted most of the spermatophore wall. The thickness of the outer layer was half of that of the medium layer. It was basophilic and stained positively with the PAS procedure (Figure 3C). 

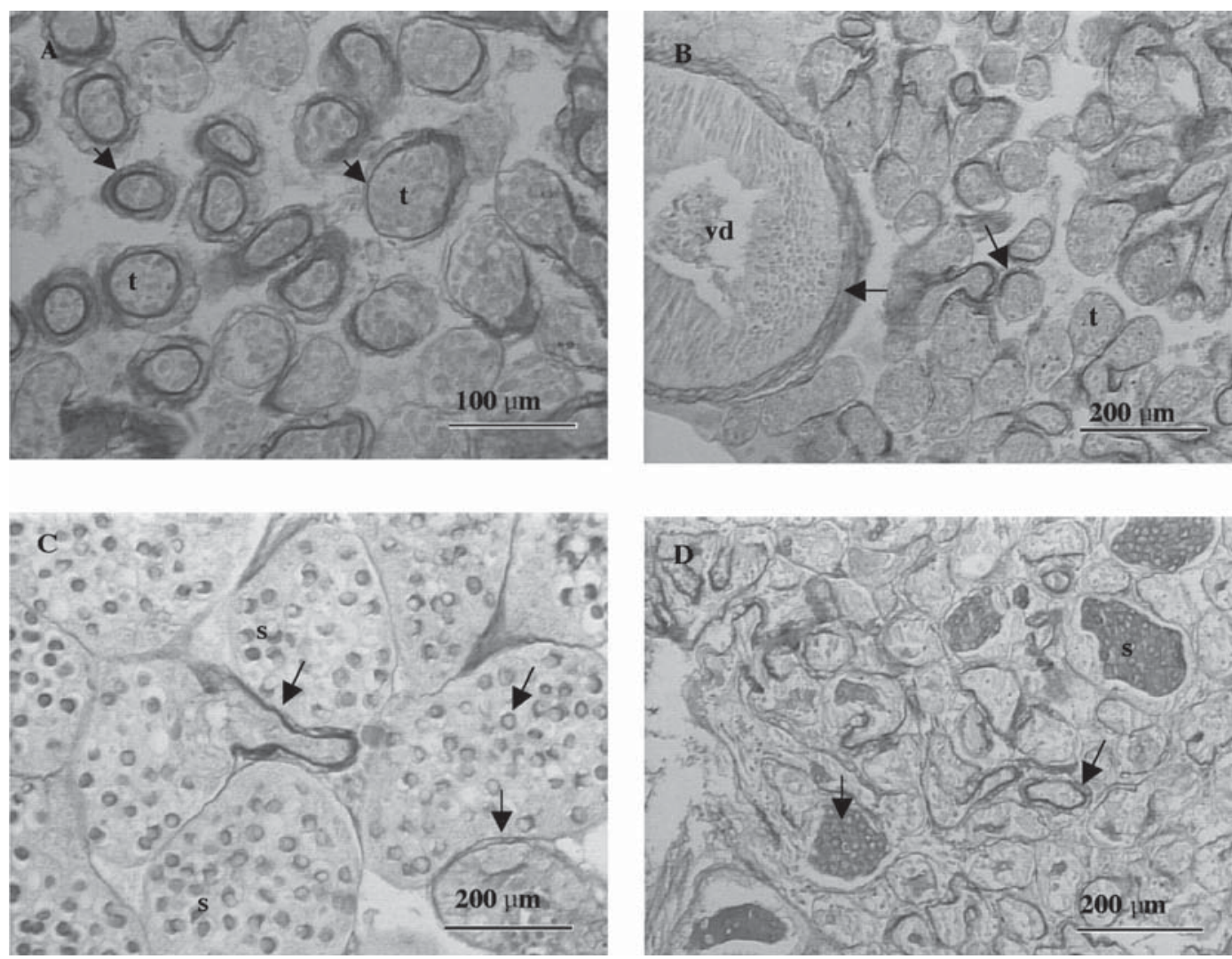

\section{Figure 2}

PAS reaction in the seminiferous tubules and the vasa deferentia of $A$. astacus caught in May (A), July (B), September (C) and November (D). Positive reaction is found in connective tissue which surrounds seminiferous tubules and vasa deferentia, basal membranes, and in acrosomal vesicle of spermatozoa. $\rightarrow$ PAS reaction; $\mathrm{t}$ - seminiferous tubule; $\mathrm{s}$ - spermatozoa; vd - vas deferens.

\section{Figure 2}

Réaction PAS dans les tubules séminifères et les canaux déférents des $A$. astacus prises au mois de mai (A), juillet (B), septembre (C) et novembre(D). On a trouvé une réaction positive dans le tissu connectif qui entoure les tubules séminifères, les canaux déférents et les membranes basales aussi bien que dans les vésicules acrosomatiques des spermatozoa. $\rightarrow$ réaction PAS; $t$ - tubule séminifère; $s$ - spermatozoa ; vd - canaux déférents. 

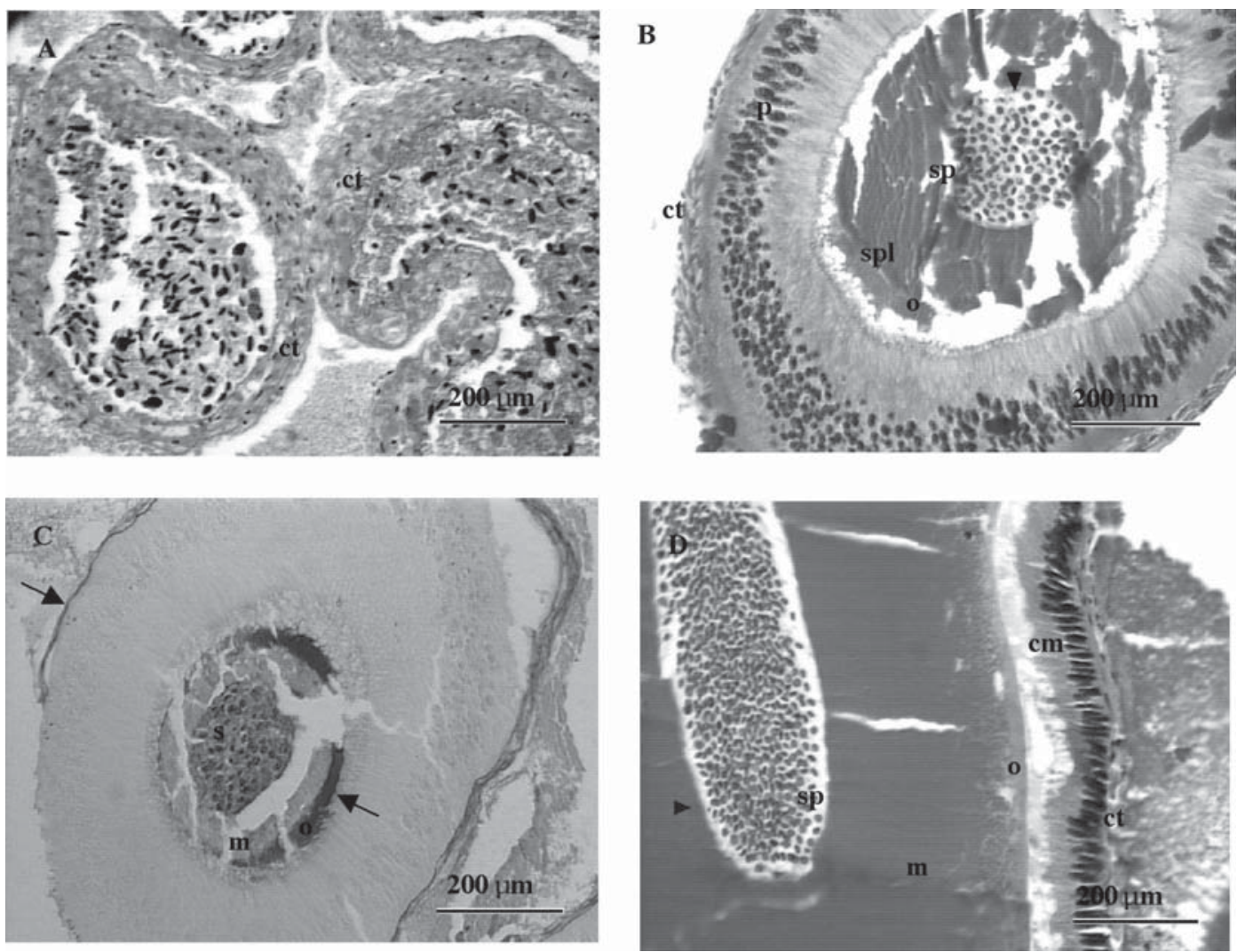

Figure 3

Vasa deferentia of A. astacus caught in June (A), September (B), October (C) and December (D). Vasa deferentia are surrounded with connective tissue and composed of secretory epithelium. Spermatophore contains spermatozoa, which are surrounded by three layers. cm - columnar ciliated epithelium; p - pseudostratified columnar ciliated epithelium; ct - connective tissue; s - spermatozoa; sp - spermatophore; spl - spermatophore acellular layers; $\boldsymbol{\nabla}$ - inner layer; $\mathrm{m}$ - medial layer; 0 - outer layer; $\rightarrow$ PAS reaction. H \& E method and PAS reaction (Figure $3 \mathrm{C}$ ).

Figure 3

Canaux déférents des $A$. astacus prises au mois de mai (A), septembre (B), octobre (C) et décembre(D). Les canaux déférents sont entourés de tissu connectif et composés d'épithélium sécreteur, le spermatophore contient des spermatozoa entourés de trois couches. $\mathrm{cm}$ - épithélium allongé et cilié ; $\mathbf{p ~ - ~}$ épithélium pseudostratifié allongé et cilié ; ct - tissu connectif ; $\mathbf{s}$ - spermatozoa ; sp - spermatophore ; spl - couches acellulaires de spermatophore ; $\mathbf{\nabla}$ - couche interne ; $m$ - couche médiane ; o - couche externe ; $\rightarrow$ réaction PAS. Méthode $\mathrm{H}$ \& E et réaction PAS (Figure $3 \mathrm{C}$ ). 
The ovaries of $A$. astacus were covered by a very thin connective tissue layer (Figure 4B). In ovaries of $A$. astacus caught in May the oosorption of unspawned oocytes was recorded (Figure 4A). The ovarian epithelium (follicular cells) was scattered and unorganized while oocytes at different stages of oogenesis were disintegrating. Two months later, the first previtellogenic oocytes were recorded (Figure 4B), follicular cells were partly attached to the oocytes but many of them were still scattered in ovaries. In August, most of the ovarian lumen was filled with previtellogenic oocytes (Figure 4C) but the first vitellogenic oocytes were already present as well as it was demonstrated by the PAS reaction (Figure 4D). At the same ovarian sections, the follicular cells were clearly attached to the periphery of each oocyte thus forming oogenetic pouches (Figures 4C and D). Yolk concentrated first in the peripheral cytoplasm of oocytes (Figures 4D, E and F). In the vitellogenic oocytes of ovaries sampled in September (Figures 4E and F) yolk filled most of their ooplasm and yolk droplets were intensively acidophilic. The germarium was centrally located in the ovarian lumen and even in September (Figures 4E and F) it contained oogonia and previtellogenic oocytes, which were only partly surrounded by follicular cells. The PAS reaction was more intensive in vitellogenic than previtellogenic oocytes (Figures 4D and F).
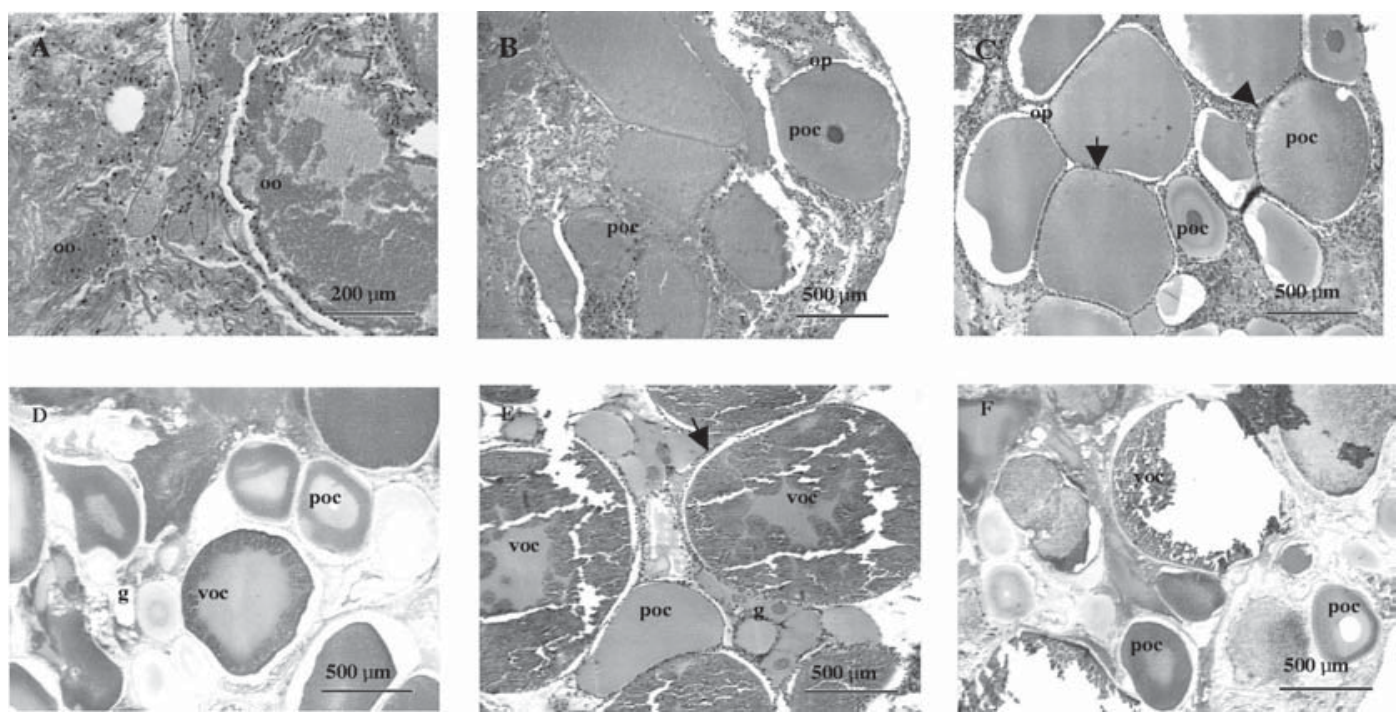

\section{Figure 4}

Ovaries of the A. astacus caught in May (A), July (B), August (C and D) and September (E and F). Ovaries contain unspawned eggs, previtellogenic or vitellogenic oocytes surrounded by follicular epithelium. oo - oosorption of unspawned eggs; poc - previtellogenic oocytes; op - oogenetic pouches; $\rightarrow$ follicular epithelium; voc - vitellogenic oocytes; g - germarium. H \& E method (Figures A, B, C and E), PAS reaction (Figures D and F).

Figure 4

Ovaires des $A$. astacus prises au mois de mai (A), juillet (B) août (C et $D$ ) et septembre ( $E$ et $F)$. Les ovaires contiennent des œufs pas encore frayés, les oocytes prévitellogéniques ou vitellogéniques entourés par l'épithélium folliculaire. oo-oosorption des œufs pas encore frayés; poc-oocytes previtellogéniques; op - poches oogénétiques; $\rightarrow$ épithélium folliculaire; voc - oocytes vitellogéniques; $g$ - germarium. Méthode H \& E (Figures A, B, C et E), Réaction PAS (Figures D et F). 


\section{DISCUSSION}

The absence of females in traps from November to June is the result of their apparent inactivity while bearing eggs, which is in agreement with the results of other authors (ACKEFORS, 1999; ALEKNOVICH et al., 1999). Glair glands were the first time noticed in August, similarly to the observation of ACKEFORS (1999) in Sweden, but mature testes were first recorded in September, which is a month later then reported by TAUGBØL et al. (1988) in Norway. As the preparation for mating depends on temperature fall, it occurs earlier in the north of Europe then in the south of the continent (Croatia). The maturation of eggs, which was indicated by the changes of their colours from white to brown, was earlier described by ACKEFORS (1999). Mature, brown coloured eggs were found for the first time in August, which could be connected with the appearance of the first vitellogenic oocytes in the histological sections of ovaries in the same month. The presence of immature white eggs even during the mating period in October is in agreement with the findings of ACKEFORS (1999) and it is confirmed by the histological sections. MCREA and MITCHELL (1995) reported that immature eggs could mature during the next reproductive season or be reabsorbed by atresia. Most of the oocytes observed on histological sections in May were reabsorbing. The beginning of the egg maturation was indicated by the appearance of yellow eggs in June while histological findings indicated that maturation of previtellogenic oocytes was progressing during July.

Mature swollen testis were first recorded in September which corresponds with the appearance of first mature spermatozoa in seminiferous tubules of testis sampled the same month and the occurrence of the first spermatophores in the vas deferens sampled also in September. These findings confirmed that the exterior observation of gonads of crayfish is in accordance with the histological analysis. Oogenesis started a month earlier (the first previtellogenic oocytes were observed in July) than spermatogenesis, indicating that the energy demands for oogenesis are greater then the energy demands of the spermatogenesis (GHERARDI, 2002). Spermatophores were present in the vas deferens in November and December that is the period when probably mating occurs in this species in Croatia.

The gradual increment of gonadosomatic index while approaching to mating season was also recorded in other decapod species (PALACIOS et al., 2000; ZAPATA et al., 2003; CARMONA-OSALDE et al., 2004). The gonadosomatic indices of males fluctuated within a very small range during reproductive period $(0.2-1.5 \% \mathrm{GSI})$, similarly to the findings of YAMAGUCHI (2001) with Uca lactea. On the other hand, the relative weight of the ovaries increased more than 25 times compared to the weight at the beginning of reproductive period and GSI was as high as $12.3 \%$. The moisture content is inversely related to their energy content (JUSSILA and MANNONEN, 1997). Our findings demonstrated that energy was accumulated much more in ovaries then in testes (aprox. $70 \%$ of GM recorded in ovaries compared to $84 \%$ of GM recorded in testes sampled in September). The measured gonadosomatic indices confirmed the fact that the contribution of females to reproduction process is much greater then the contribution of males (GHERARDI, 2002). Decline in the moisture content of the testes after the mating period is probably related to the storage of energy reserves prior to the winter starvation period, while lower GM recorded in ovaries sampled in May probably indicated oosorption, which was noticed on histological section of ovaries sampled the same month.

Histological observations of seminiferous tubules indicated that also the connective tissue, which surrounds seminiferous tubules is going through changes during the reproductive cycle. Differences in the appearance of the connective tissue and changes in the intensity of the PAS reaction were observed. Because of the enlargement of the seminiferous tubule radius during spermatogenesis, the connective tissue becomes thinner and it affects the intensity of the PAS coloration of glycoprotein and glycolipid, which are attached to the cellular membranes of fibrocytes and also to the basal membrane of the 
germinative epithelium. An intensive PAS coloration of empty seminiferous tubules was detected in November. No more than two developmental stages of spermatozoa was found in one segment of seminiferous tubule which indicated synchrony of spermatogenesis together with the similar appearance of seminiferous tubules in particular regions of the testes, which is also in agreement with the literature results (OBRADOVIĆ, 1982; KROL et al., 1992). The positive PAS staining of the acrosomal vesicle of spermatozoa detected in histological sections confirmed the literature results (KROL et al., 1992).

Considerable changes of the connective tissue and epithelium surrounding the vas deferens were detected as well. In May and June, the connective tissue was thick while the lumen of vas deferens was surrounded by a simple squamous epithelium and filled with the remains of spermatophores. A month later and further on we detected well developed pseudostratified columnar epithelium which was ciliated rather then having microvillus border as it was described by KROL et al. (1992). At the same time, the connective tissue became thinner as the vas deferens was stretching. The detected alteration of the epithelium is connected with its function of producing acellular layers of spermatophore walls. Cilia noticed at the apical surface of the epithelial cells probably help the transport of gametes down to the ducts and a similar ciliated epithelium is usually present in the ductus epididymis of mammals (HAMMERSEN, 1985). In December the pseudostratified columnar ciliated epithelium was transformed into a single layered columnar ciliated epithelium and to a single layered cuboidal epithelium in the vas deferens. Obviously, the reproductive cycle induced a reversible metaplasia of the epithelium, which is connected with the transport of spermatozoa through the vas deferens and the production of the spermatophore's layers. Three acellular layers of the spermatophore wall were visible and this finding is in agreement with the literature data (VOGT, 2002). From these three layers, only the outer layer of the spermatophore wall stained positively with the PAS procedure which indicates its polysaccharide content.

The absence of a thin muscle layer covering the ovaries is in agreement with the hypothesis of ADIYODI and SUBRAMONIAM (1983). In this species germinal epithelium is situated centrally in ovaries and it was clear that both the oocytes and follicular cells were derived from it as it was described in literature (KROL et al., 1992; VOGT, 2002). Central lumen of the ovary is not evident as in many other decapod species (KROL et al., 1992). Oogenesis is synchronised within ovaries as indicated by dominance of previtellogenic or vitellogenic oocytes in ovaries sampled at different months but immature oocytes were constantly produced independently on the progress of reproductive cycle. Similarly to MCREA and MITCHELL (1995) and ACKEFORS (1999) we found that immature eggs go through atresia (sections of ovaries sampled in May). Yolk accumulated first in the peripheral cytoplasm, similarly to lobsters and other crayfish species (YANO, 1988) and the PAS reaction was more intensive in vitellogenic ooocytes than in previtellogenic oocytes, which indicate the presence of a polysaccharide component of the yolk which is similar to other invertebrate species (UNUMA et al., 2003)

\section{CONCLUSIONS}

The reproductive cycle of $A$. astacus is characterized by the enlargement of gonads, both in males and females but it is more pronounced in ovaries then in testes $(0.2-1.5 \%$ and $12.3 \%$, respectively). The moisture content of the gonads decreases during the reproductive period, which indicates the storage of energy reserves prior to mating. During the maturation of the germinative cells in the testis, morphological changes in the connective tissue surrounding the seminiferous tubules, the vas deferens and changes in the secretory epithelium of the vas deferens were detected. The maturation of germinative cells is synchronized, both in testes and ovaries and could be accurately interpreted by the external observation of reproductive organs. 


\section{ACKNOWLEDGEMENTS}

This research has been done as a part of a project financed by Ministry of Science, Education and Sport of Republic Croatia nr. 119-128. We thank Mrs. Zrinka Benčina who has made all the histological procedures. Special thank to Dr. Miklós Puky for reviewing the manuscript and for valuable comments and also to two unknown referees on revision of the manuscript. Thank to Mrs Banovič for the French translation.

\section{REFERENCES}

ABDU U., YEHEZKEL G., SAGI A., 2000. Oocyte development and polypeptide dynamics during ovarian maturation in the red-claw crayfish Cherax quadricarinatus. Inv. Repr. Dev., 37, 75-83.

ACKEFORS H.E.G., 1999. Observations on the Yearly Life Cycle of Astacus astacus in a Small Lake in Sweden. Freshwater Crayfish, 12, 413-429.

ADIYODI K.G., SUBRAMONIAM T., 1983. Arthropoda -Crustacea. In: ADIYODI K.G. and ADIYODI R.G. (Eds.), Reproductive Biology of Invertebrates: Oogenesis, Oviposition and Oosorption, Vol. 1, 443-495, Wiley and Sons, London.

ADIYODI K.G., ANIKUMAR G., 1988. Arthropoda - Crustacea. In: ADIYODI K.G. and ADIYODI R.G. (Eds.), Reproductive Biology of Invertebrates: Accessory Glands, Vol. 3, 261-318, Oxford \& IBH Publishing, New Delhi, India.

ALEKNOVICH A., KULLESH V., ABLOV S., 1999. Growth and Size Structure of Narrowclawed crayfish Astacus leptodactylus Esch. in its Eastern Area. Freshwater Crayfish, 12, 550-554.

ANDO H., MAKIOKA T., 1999. Structure of the ovary and mode of oogenesis in a freshwater crab Potamon dehaani. J. Morphol., 239, 107-114.

BROWDY C.L., FAINZILBER M., TOM M., LOYA Y., LUBZENS E., 1990. Vitellin synthesis in relation to oogenesis in in vitro-incubated ovaries of Penaeus semisulculatus (Crustacea, Decapoda, Penaeidae). J. Exp. Zool., 255, 205-215.

CARMONA-OSALDE C., RODRÍGUEZ-SERNA M., OLVERA-NOVOA M.A., GUTIÉRREZYURRITA P.J., 2004. Gonadal development, spawning, growth and survival of the crayfish Procambarus llamasi at three different water temperature. Aquaculture, 232, 305-316.

GHERARDI F., 2002. Behaviour. In: HOLDICH D.M (Ed.), Biology of Freshwater Crayfish, 258-291, Blackwell Science, London.

HAMMERSEN F., 1985. Männliche Geschlechtsorgane. In Histologie - Farbatlas der Mikroskopischen Anatomie, 182, Urban \& Schwarzenberg, München.

JUSSILA J., 1997. Physiological Responses of Astacid and Parastacid Crayfishes (Crustacea: Decapoda) to Conditions of Intensive Culture. Doctoral Dissertation, University of Kuopio, Finland, 17-137.

JUSSILA J., MANNONEN A., 1997. Marron (Cherax tenuimanus) and noble crayfish (Astacus astacus) hepatopancreas energy and its relationship to moisture content. Aquaculture, 149, 157-161.

KROL R.M., HAWKINS W.E., OVERSTREET R.M., 1992. Reproductive components. In HARRISON F.W. and RUPPERT E. (Eds.) Microscopic Anatomy of Invertebrates: Decapod Crustacea Vol. 10, 295-343, Wiley-Liss Inc., New York.

MCRAE T.G., MITCHELL B.D., 1995. Studies on ovarian development in the yabby, Cherax albidus Clark. Freshwater Crayfish, 10, 521-531. 
MEUSY J.J., PAYEN G.G., 1988. Female reproduction in malacostracan crustacean. Zool. Sci. , 5, 217-265.

MINAGAWA M., CHIU J.R., KUDO M., ITO F., TAKASHIMA F., 1993. Female reproductive biology and oocyte development of the red frog crab, Ranina ranina, off Hachijojima, Izu Islands, Japan. Mar. Biol., 115, 613-623.

OBRADOVIĆ J., 1982. Histomorphological features of the male reproductive organs of the noble crayfish (Astacus astacus L.). Doctoral disertation, Faculty of Veterinary Medicine, University of Zagreb 1-116 (in Croatian).

O'DONOVAN P., ABRAHAM M., COHEN D., 1984. The ovarian cycle during the intermoult in ovigerous Macrobarchium rosenbergi. Aquaculture, 36, 347-358.

PALACIOS E., IBARRA A.M., RACOTTA I.S., 2000. Tissue biochemical composition in relation to multiple spawning in wild and pond-reared Penaeus vannamei broodstock. Aquaculture, 185, 353-371.

SELLOS D., LEGAL Y., 1981. Changes in basic nuclear proteins during sperm maturation in Palaemon serratus (Crustacea, Natantia). Cell Growth Differ., 10(2), 69-77.

SUBRAMONIAM T., 2000. Crustacean ecdysteroids in reproduction and embryogenesis. Comp. Biochem. Physiol., C 125(2), 135-156.

ŠVOB M., 1974. Histological and histochemical methods, 196, Svjetlost, Sarajevo, (in Croatian).

TAN-FERMIN, J.D., PUDADERA, R.A., 1989. Ovarian maturation stages of the wild giant tiger prawn, Penaeus monodon Fabricius. Aquaculture, 78, 229-242.

TAUGBØL T., SKURDAL J., FJELD E., 1988. Maturity and fecundity of Astacus astacus females in Norway. Freshwater Crayfish, 7, 107-114.

UNUMA T., YAMAMOTO, T., AKIYAMA, T., SHIRAISHI, M., OHTA, H., 2003. Quantitative changes in yolk protein and other components in the ovaries and testis of the sea urchin Pseudocentrotus depressus. J. Exp. Biol., 206, 365-372.

VOGT G., 2002. Functional Anatomy. In HOLDICH D.M. (Ed.), Biology of Freshwater Crayfish, 53-152, Blackwell Science, London.

WESTMAN K., PURSIAINEN M., VILKMAN R., 1998. A new folding trap model which prevents crayfish from escaping. Freshwater Crayfish, 4, 235-242.

YAMAGUCHI T., 2001. Seasonal changes of the hepatopancreas index in the males of the fiddler crab, Uca lactea. Crustaceana, 74(7), 627-634.

YANO I., 1988. Oocyte development in the "kuruma" prawn, Penaeus japonicus. Comp. Biochem. Physiol., 86B, 213-218.

ZAPATA V., LÓPEZ GRECO L.S., MEDESANI D., RODRÍGUEZ E.M., 2003. Ovarian growth in the crab Chasmagnathus granulata induced by hormones and neuroregulators throughout the year. In vivo and in vitro studies. Aquaculture, 224, 339-352. 
